\title{
Activity of dietary fatty acids on FFA1 and FFA4 and characterisation of pinolenic acid as a dual FFA1/FFA4 agonist with potential effect against metabolic diseases
}

\author{
Elisabeth Christiansen ${ }^{1}$, Kenneth R. Watterson ${ }^{2}$, Claire J. Stocker ${ }^{3}$, Elena Sokol ${ }^{4}$, Laura Jenkins ${ }^{2}$, \\ Katharina Simon ${ }^{5}$, Manuel Grundmann ${ }^{5}$, Rasmus K. Petersen ${ }^{6}$, Edward T. Wargent ${ }^{3}$, Brian D. Hudson ${ }^{2}$, \\ Evi Kostenis ${ }^{5}$, Christer S. Ejsing ${ }^{4}$, Michael A. Cawthorne ${ }^{3}$, Graeme Milligan ${ }^{2}$ and Trond Ulven ${ }^{1 *}$ \\ ${ }^{1}$ Department of Physics, Chemistry and Pharmacy, University of Southern Denmark, Campusvej 55, \\ DK-5230 Odense $M$, Denmark \\ ${ }^{2}$ Molecular Pharmacology Group, Institute of Molecular, Cell and Systems Biology, College of Medical, Veterinary and \\ Life Sciences, University of Glasgow, Glasgow G12 8QQ, Scotland, UK \\ ${ }^{3}$ Buckingham Institute of Translational Medicine, University of Buckingham, Hunter Street, Buckingham MK18 $1 E G$, UK \\ ${ }^{4}$ Department of Biochemistry and Molecular Biology, Villum Center for Bioanalytical Sciences, University of Southern \\ Denmark, Campusvej 55, DK-5230 Odense M, Denmark \\ ${ }^{5}$ Institute of Pharmaceutical Biology, University of Bonn, Nussallee 6, D-53115 Bonn, Germany \\ ${ }^{6}$ Department of Biology, University of Copenhagen, Ole Maaløes Vej 5, DK-2200, Copenhagen N, Denmark
}

(Submitted 14 January 2015 - Final revision received 11 March 2015 - Accepted 16 March 2015 - First published online 28 April 2015)

\section{Abstract}

Various foods are associated with effects against metabolic diseases such as insulin resistance and type 2 diabetes; however, their mechanisms of action are mostly unclear. Fatty acids may contribute by acting as precursors of signalling molecules or by direct activity on receptors. The medium- and long-chain NEFA receptor FFA1 (free fatty acid receptor 1, previously known as GPR40) has been linked to enhancement of glucose-stimulated insulin secretion, whereas FFA4 (free fatty acid receptor 4, previously known as GPR120) has been associated with insulin-sensitising and anti-inflammatory effects, and both receptors are reported to protect pancreatic islets and promote secretion of appetite and glucose-regulating hormones. Hypothesising that FFA1 and FFA4 mediate therapeutic effects of dietary components, we screened a broad selection of NEFA on FFA1 and FFA4 and characterised active compounds in concentration-response curves. Of the screened compounds, pinolenic acid, a constituent of pine nut oil, was identified as a relatively potent and efficacious dual FFA1/FFA4 agonist, and its suitability for further studies was confirmed by additional in vitro characterisation. Pine nut oil and free and esterified pure pinolenic acid were tested in an acute glucose tolerance test in mice. Pine nut oil showed a moderately but significantly improved glucose tolerance compared with maize oil. Pure pinolenic acid or ethyl ester gave robust and highly significant improvements of glucose tolerance. In conclusion, the present results indicate that pinolenic acid is a comparatively potent and efficacious dual FFA1/FFA4 agonist that exerts antidiabetic effects in an acute mouse model. The compound thus deserves attention as a potential active dietary ingredient to prevent or counteract metabolic diseases.

Key words: NEFA: FFAR1: G protein-coupled receptor 40: FFAR4: G protein-coupled receptor 120: Pinolenic acid: Type 2 diabetes

Obesity and type 2 diabetes (T2D) constitute a major health problem in our society. In 2014, the number of diabetics worldwide reached 387 million and was forecasted to reach 592 million by 2035, with T2D accounting for $90 \%$ of the cases $^{(1)}$. In addition to a sedentary lifestyle, diet is a major player in the development and control of metabolic diseases. Various foods, such as the Mediterranean $\operatorname{diet}^{(2)}$, fibre-rich $\operatorname{diets}^{(3)}$, dairy products ${ }^{(4)}$, coffee $^{(5)}$ and marine oils ${ }^{(6,7)}$, have been associated with protective effects against metabolic disorders $^{(8)}$; however, the active ingredients in foodstuff and their mechanisms of action are largely unknown ${ }^{(9)}$. $\mathrm{NEFA}^{(10,11)}$ are known to exert biological effects by acting as precursors of various oxidised messenger molecules and by acting directly on both intracellular and cell surface

Abbreviations: BRET, bioluminescence resonance energy transfer; DMR, dynamic mass redistribution; DMSO, dimethylsulphoxide; FFA1-4, free fatty acid receptors 1-4; HEK, human embryonic kidney; GLA, $\gamma$-linolenic acid; T2D, type 2 diabetes; TFA, trans-fatty acid. 
receptors $^{(8)}$. Their established biological activities suggest fatty acids as interesting potential candidates for active ingredients responsible for dietary health effects. The fatty acid receptors FFA1, FFA2, FFA3 and FFA4 are G proteincoupled 7-transmembrane receptors activated by different groups of NEFA and have all been associated in various ways with T2D and other metabolic and inflammatory disorders. FFA1 and FFA 4 are activated by medium- to long-chain NEFA and are believed to be possible therapeutic targets for the treatment of T2D and obesity ${ }^{(9-12)}$. FFA2 and FFA3 are activated by $\mathrm{SCFA}^{(13-15)}$ and are highly expressed in the intestines where SCFA are produced by bacterial fermentation of dietary fibre ${ }^{(16,17)}$, and may therefore be involved in mediating some of the beneficial effects of dietary fibre on obesity and $\mathrm{T} 2 \mathrm{D}^{(18,19)}$.

FFA1 is highly expressed in pancreatic $\beta$-cells and enhances glucose-stimulated insulin secretion in response to various medium- and long-chain $\mathrm{NEFA}^{(10,20,21)}$. The receptor has been clinically validated as a target for treatment of T2D by a phase 2 clinical study with the synthetic agonist fasiglifam ${ }^{(22)}$. FFA1 is also expressed in enteroendocrine cells where it has been associated with release of glucose- and appetiteregulating hormones such as glucagon-like peptide-1, glucosedependent insulinotropic polypeptide and cholecystokinin ${ }^{(23-25)}$. FFA4 is expressed in intestinal enteroendocrine cells, where activation is reported to increase secretion of glucagon-like peptide-1, although this is controversial, and to inhibit secretion of the orexigenic hormone ghrelin ${ }^{(12,26-28)}$. The receptor is also expressed in the pancreas, adipose tissue, macrophages and the brain, where it has been associated with the protection of islets, improvement of insulin sensitivity and the mediation of anti-inflammatory and appetite-lowering effects ${ }^{(29-33)}$. Notably, a lack of FFA4 in mice or dysfunctional FFA4 in humans has been linked to increase the risk of obesity ${ }^{(34)}$ These observations suggest that FFA 4 may protect against diet-induced obesity and improve glycaemic control. In the present study, we examined the activity of dietary fatty acids on FFA1 and FFA4. Of these, pinolenic acid was selected for additional in vitro characterisation, and the potential of pine nut oil and pinolenic acid as anti-diabetic agents was evaluated in mouse studies.

\section{Experimental methods}

\section{Materials and compounds}

Acetic acid was acquired from VWR, $22: 5 n-6$ from Santa Cruz Biotechnology and 5-oxo-6E,8Z,11Z,14Z-eicosatetraenoic acid (5-Oxo-ETE) was synthesised according to a published procedure ${ }^{(35)}$. Pinolenic acid $(5,9,12-18: 3 n-6)$, pinolenic acid ethyl ester, $18: 4 n-3,20: 3 n-3,22: 3 n-3$ and $c 18, t 11, t 13-$ $18: 3 n-5$ were from Cayman Chemicals, and the remaining NEFA and dimethylsulphoxide (DMSO) were acquired from Sigma-Aldrich. The pine nut oils were acquired from Huilerie Beaujolaise (FA-60), Siberian Pine Nut Oil (FA-61), Siberian Pine Nut Oil enriched with 10\% resin (FA-62) and Siberian Tiger Natural, Inc. (FA-64). $10 \% \mathrm{H}_{2} \mathrm{SO}_{4}$ in methanol, butylated hydroxytoluene and water-free methanol were purchased from Sigma-Aldrich. $n$-Hexane was obtained from Fisher Scientific.

\section{NEFA stock solutions}

The NEFA were dissolved in DMSO to $10 \mathrm{~mm}$, unless otherwise stated. The solubility of each stock solution was checked by visual inspection after 100-fold dilution in $10 \mathrm{~mm}$-phosphate buffer at $\mathrm{pH} 7 \cdot 4$. The stock solutions of the saturated NEFA were prepared on the basis of individual solubility: 6:010:0 were dissolved to $100 \mathrm{~mm}$ in DMSO, 11:0 was dissolved to $50 \mathrm{~mm}$ in DMSO, 12:0-14:0 were dissolved to $10 \mathrm{~mm}$ in DMSO, 15:0-18:0 were dissolved to $1 \mathrm{~mm}$ in DMSO, 19:022 : 0 were dissolved to $0.5 \mathrm{~mm}$ in DMSO and 23:0 was dissolved to a saturated solution in DMSO approximately $0.5 \mathrm{~mm}$. The PUFA and oxidised NEFA 24:1n-9, 20:3n-6, $22: 4 n-6, \quad t 10, c 12-18: 2 n-6, \quad 16-\mathrm{OH}-16: 0$ and $12-\mathrm{OH}-18: 0$ were prepared as $5 \mathrm{~mm}$ in DMSO and perfluorotetradecanoic acid as $2 \mathrm{~mm}$ in DMSO.

\section{Cell culture}

Human embryonic kidney (HEK) 293T cells were maintained in Dulbecco's modified Eagle's medium supplemented with $10 \%$ fetal bovine serum at $37^{\circ} \mathrm{C}$ and $5 \% \mathrm{CO}_{2}$. In addition, stable cell lines with tetracycline-inducible expression of the receptor of interest were generated using the Flp-In ${ }^{\text {TM }}$ T-REx $^{\text {TM }} 293$ cell system (Life Technologies) as described previously $^{(36-38)}$, and utilised to study NEFA receptor-induced $\mathrm{Ca}^{2+}$ mobilisation and dynamic mass redistribution (DMR).

\section{Plasmids}

Plasmids encoding either the human or mouse FFA1 or FFA4 (short isoform) receptors with enhanced yellow fluorescent protein fused to their $\mathrm{C}$ terminal and incorporating a $\mathrm{N}$ terminal FLAG epitope tag (FFA4 constructs only) in the pcDNA5 FRT/TO expression vector were generated as previously described $^{(36)}$

\section{$\beta$-Arrestin-2 interaction assay}

$\beta$-Arrestin-2 recruitment to either human or mouse isoforms of FFA1 and FFA4 was measured using a bioluminescence resonance energy transfer (BRET)-based approach, as previously described $^{(36)}$. Briefly, HEK 293T cells were co-transfected with enhanced yellow fluorescent protein-tagged forms of each receptor in a 4:1 ratio with a $\beta$-arrestin-2 Renilla luciferase plasmid using polyethylenimine. Cells were then transferred into white ninety-six-well plates at $24 \mathrm{~h}$ post-transfection. At $48 \mathrm{~h}$ post-transfection, cells were washed to remove fatty acids that may be present in the culture medium and the culture medium replaced with Hanks' balanced salt solution immediately before conducting the assay. For FFA4, cells were incubated with $2.5 \mu \mathrm{m}$ of the Renilla luciferase substrate coelenterazine $\mathrm{h}$ at $37^{\circ} \mathrm{C}$ for $10 \mathrm{~min}$ and the cells were then stimulated with NEFA samples for a further $5 \mathrm{~min}$ at $37^{\circ} \mathrm{C}$. For FFA1, cells were incubated with NEFA samples for 
$15 \mathrm{~min}$ at $37^{\circ} \mathrm{C}$. Coelenterazine $\mathrm{h}(2.5 \mu \mathrm{M})$ was then added to the cells for a further $15 \mathrm{~min}$ at $37^{\circ} \mathrm{C}$. BRET, resulting from NEFA receptor $-\beta$-arrestin- 2 interaction, was then determined by measuring the ratio of luminescence at 535 and $475 \mathrm{~nm}$ using a Pherastar FS fitted with the BRET1 optic module (BMG Labtech).

\section{$\mathrm{Ca}^{2+}$ mobilisation}

$\mathrm{Ca}^{2+}$ assays were carried out on Flp-In T-Rex 293 cell lines, generated to inducibly express either FFA4 or FFA1 upon treatment with doxycycline. One day before conducting the experiment, cells were seeded at 50000 cells/well in black clear-bottom ninety-six-well microplates. Cells were allowed to adhere for $3-4 \mathrm{~h}$ before the addition of $100 \mathrm{ng} / \mathrm{ml}$ doxycycline to induce receptor expression. The following day, cells were incubated in culture medium containing the $\mathrm{Ca}^{2+}$-sensitive dye Fura2-AM $(3 \mu \mathrm{M})$ for $45 \mathrm{~min}$. Cells were then washed three times to remove fatty acids present in the culture medium and then allowed to equilibrate for $15 \mathrm{~min}$ in Hanks' balanced salt solution (HBSS) before conducting the assay. Fura2 fluorescent emission was measured at $510 \mathrm{~nm}$ following excitation at both 340 and $380 \mathrm{~nm}$ during the course of the experiment using a Flexstation plate reader (Molecular Devices). $\mathrm{Ca}^{2+}$ responses were then measured as the difference between 340:380 ratios before and after the addition of NEFA samples.

\section{PPAR assay}

A mouse embryo fibroblast cell line was used for PPAR $\alpha$, PPAR $\delta$ or PPAR $\gamma$ transfections. Cells were propagated in Dulbecco's modified Eagle's medium supplemented with 10\% fetal calf serum and antibiotics. For transfections, cells were transfected in solution by Metafectene lipofection, essentially according to the manufacturer's (Biontex) instructions and seeded in Dulbecco's modified Eagle's medium supplemented with 10\% fetal calf serum and antibiotics in ninety-six-well dishes at 24000 cells $/ \mathrm{cm}^{2}$. The transfection plasmid mix included the Gal4-responsive luciferase reporter, the expression vector for the fusion between the Gal4 DNA-binding domain and the ligand binding domain of human PPAR $\alpha$, PPAR $\delta$ or PPAR $\gamma$, and a cytomegalovirus promoter driven Renilla normalisation vector. $6 \mathrm{~h}$ after seeding the transfected cells, new media containing the DMSO vehicle $(0 \cdot 1-0 \cdot 5 \%)$, positive control (GW7647 (30 nM) for PPAR $\alpha$, GW501516 (100 nM) for PPAR $\delta$ or rosiglitazone $(1 \mu \mathrm{M})$ for PPAR $\gamma)$ or the test compound was added. Approximately $18 \mathrm{~h}$ later, cells were harvested and lysates analysed for Photinus and Renilla luciferase activity by luminometry. All data points were performed in at least six replications. Luminometer raw data was analysed in Microsoft Excel spreadsheets and presented as column graphs depicting average values and standard deviations.

\section{Label-free dynamic mass redistribution assay}

Cell-based DMR assays were recorded as described previously in detail ${ }^{(39,40)}$, using a beta version of the Corning ${ }^{\circledR}$ Epic ${ }^{\circledR}$ Biosensor (Corning) or the Enspire $\AA^{\circledR}$ benchtop optical label-free system in conjunction with the Mini Janus liquid handling station (Perkin Elmer). HEK 293 (HEK) cells were stably transfected with human FFA1 receptor or human FFA4 using the Flp-In ${ }^{\mathrm{TM}}$ T-REx ${ }^{\mathrm{TM}}$ system according to the manufacturer's instructions (Life Technologies).

Cells were seeded at a density of 18000 cells/well (FFA1-HEK, FFA4-HEK and HEK 293) on fibronectin-coated biosensor plates and were cultivated overnight $\left(37^{\circ} \mathrm{C}, 5 \% \mathrm{CO}_{2}\right)$ to obtain confluent monolayers. Afterwards, cells were washed twice with Hanks' balanced salt solution (HBSS) containing 20 mM-HEPES and $0 \cdot 1 \%$ bovine serum albumin and incubated for at least $1 \mathrm{~h}$ in the Epic ${ }^{\circledR}$ reader at $37^{\circ} \mathrm{C}$. The sensor plate was then scanned and a baseline optical signature was recorded. Hereafter, compound solutions were transferred into the biosensor plate and DMR was monitored for at least $4000 \mathrm{~s}$. All optical DMR recordings are buffer-corrected. Quantification of DMR signals for concentration effect curves was calculated by maximum response within $1800 \mathrm{~s}$. Data calculation was performed using GraphPad Prism 5.04 (GraphPad Software).

\section{Fatty acid profiling by GC analysis}

Fatty acid methyl esters were prepared by acid-catalysed transesterification from TAG of pine nut oil or maize oil ${ }^{(41)}$. Briefly, $1 \mu \mathrm{l}$ of oil was derivatised at $60^{\circ} \mathrm{C}$ overnight with $1 \mathrm{ml}$ of $2.5 \%$ methanolic $\mathrm{H}_{2} \mathrm{SO}_{4}$ and $20 \mu \mathrm{l} 2 \mathrm{mg} / \mathrm{ml}$ butylated hydroxytoluene dissolved in dry methanol. After cooling to room temperature, $1 \mathrm{ml}$ of water and $500 \mu \mathrm{l}$ of $n$-hexane were added to the glass vials. Samples were centrifuged and $400 \mu \mathrm{l}$ of the $n$-hexane-containing upper phase were transferred into a $1 \mathrm{ml}$ auto-sampler vial for GC analysis. GC analysis was carried out using a Clarus 500 Gas Chromatograph (Perkin Elmer) equipped with a flame-ionisation detector and a capillary column (TR-FRAME, $60 \mathrm{~m} \times 0.25 \mathrm{~mm}$ inner diameter, $0.25 \mathrm{~mm}$ film thickness). Helium was used as a carrier gas at a constant flow rate of $0.8 \mathrm{ml} / \mathrm{min}$. Samples $(5 \mu \mathrm{l})$ were injected with 10:1 split ratio. The column temperature was maintained at $140^{\circ} \mathrm{C}$ for $5 \mathrm{~min}$ and then raised at a rate of $3^{\circ} \mathrm{C} / \mathrm{min}$ up to $240^{\circ} \mathrm{C}$ and maintained for $20 \mathrm{~min}$. The injection port and detector temperature were set to 250 and $260^{\circ} \mathrm{C}$, respectively. Total chromatographic run time was $58 \mathrm{~min}$. Chromatograms were processed using Total Chrome Navigator software, peak areas were used to achieve relative quantification of identified fatty acid methyl esters.

\section{Oral glucose tolerance test in mice}

Animal procedures were conducted in accordance with the University of Buckingham project licence under the UK Animals (Scientific Procedures) Act (1986) and as approved by the University's Ethics Review Board. Male C57BL/6 mice (Charles River) aged 6-7 weeks on arrival were fed a standard laboratory chow diet that contained $10 \%$ fat, $70 \%$ carbohydrate and $20 \%$ protein by energy (Beekay Feed; B\&K Universal Limited). They were housed at $21-23^{\circ} \mathrm{C}$ with lights on from 07.00 to 19.00 hours. The mice were fasted for $5 \mathrm{~h}$ before receiving an oral glucose load $(3 \mathrm{~g} / \mathrm{kg}) ; 30 \mathrm{~min}$ before receiving glucose, the mice were given pine nut oil $(1 \mathrm{~g} / \mathrm{kg})$,

\footnotetext{
sensor (Corning) or the Enspire benchtop optical label-free
} 
pinolenic acid $(100 \mathrm{mg} / \mathrm{kg})$ or ethyl pinolenate $(100 \mathrm{mg} / \mathrm{kg})$ by gavage. Control mice received maize oil $(1 \mathrm{~g} / \mathrm{kg})$ and the FFA1 agonist TUG-905 $(10 \mathrm{mg} / \mathrm{kg})$ was used as a positive control. The dosing vehicle consisted of $10 \%$ DMSO, 90\% (1:1 PEG 400:100 mm-phosphate buffer $\mathrm{pH}$ 7.4). The dosing volume was $10 \mathrm{ml} / \mathrm{kg}$. Blood samples were taken from the tail tip for glucose measurement at $30 \mathrm{~min}$ before the glucose load and after $30 \mathrm{~min}$. Further samples for glucose only were obtained at 0, 30, 60 and $120 \mathrm{~min}$ after the glucose load. Blood samples $(10 \mu \mathrm{l})$ were mixed with haemolysis reagent and blood glucose measured in duplicate using the Sigma Enzymatic (Glucose Oxidase Trinder; ThermoFisher Microgenic) colorimetric method at 505 and $575 \mathrm{~nm}$ using a SpectraMax250 (Molecular Devices Corporation).

\section{Statistical analysis}

Data analysis and curve fitting were carried out using the GraphPad Prism software package version 5.0. Potency $\left(\mathrm{pEC}_{50}\right)$ and efficacy $\left(E_{\max }\right)$ values for the NEFA were calculated from the BRET and $\mathrm{Ca}^{2+}$ data by fitting to threeparameter sigmoidal concentration-response curves. Reported pEC $_{50}$ and $E_{\max }$ values represent the mean with their standard errors of two to four independent experiments. For statistical comparison of the pinolenic acid curve-fit parameters obtained between human and mouse orthologues or between $\mathrm{Ca}^{2+}$ or arrestin-BRET assays, curve fits were generated for independent experiments and $t$ tests used to establish statistical difference between the mean $\mathrm{pEC}_{50}$ values obtained. For statistical comparison of PPAR data, $t$ tests of treatments against vehicle control were used. Results from fatty acid composition analysis are reported as means and standard deviation. Glucose tolerance data were analysed by two-way ANOVA followed by Bonferroni multiple comparisons against the vehicle-treated group. Results are presented as means with their standard errors. Statistical significance is indicated as ${ }^{*} P<0.05$, ** $P<0.01$ and ${ }^{* * *} P<0.001$.

\section{Results}

\section{Screening and characterisation of NEFA}

Since the solubility is a limiting factor in biological testing of NEFA, the solubility of the compounds was investigated by dilution of DMSO solutions by 100-fold with PBS ( $\mathrm{pH} \mathrm{7.4).}$ The concentration of the DMSO solution was reduced if PBS dilution resulted in precipitation or clouding. This gave DMSO solutions in the $0 \cdot 5-100 \mathrm{~mm}$ range (see above). Saturated NEFA with longer chain length $(\geq \mathrm{C} 24)$ were insufficiently soluble for testing. Most unsaturated NEFA were prepared as $10 \mathrm{~mm}$-DMSO stock solutions and tested at a maximal concentration of $30 \mu \mathrm{m}$. Compounds were generally screened at the highest possible concentration, and below their estimated critical micelle concentrations ${ }^{(42-44)}$, on FFA1 in a Ca mobilisation assay and on FFA 4 in a $\beta$-arrestin- 2 interaction BRET assay. Compounds exhibiting a response higher than $20 \%$ relative to the reference compounds (lauric acid for FFA1 and TUG-424 for FFA4) were characterised in full concentration-response curves (online Supplementary Figs. S1 and S2).

Screening of saturated NEFA on FFA1 and FFA4 resulted in the selection of compounds with a chain length of C10-C16 for detailed analysis. The compounds displayed similar potency on each receptor, although 10:0 and 11:0 appeared 10-fold more potent on FFA1 and vice versa for FFA4, and 14:0 and 15:0 where somewhat more potent on FFA4 (Table 1). There was a general trend towards higher efficacy for the medium-chain fatty acids and decreased efficacy towards the long-chain congeners for both receptors.

Myristoleic acid (14:1n-5) and palmitoleic acid (16:1n-7) were the most active MUFA with regard to both potency and efficacy on FFA1 and FFA4 (Table 2). Oleic acid (18:1n-9), petroselinic acid $(18: 1 n-12)$ and cis-vaccenic acid $(18: 1 n-7)$ displayed reduced efficacy on FFA4. MUFA longer than C18 were not sufficiently active on FFA 4 to qualify for full curve testing. All MUFA acted as full agonists at FFA1 except the industrial trans-fatty acid (TFA) elaidic acid (trans-18:1n-9), which behaved as a partial agonist (online Supplementary Fig. S1), and nervonic acid (24:1n-9), which was inactive. Vaccenic acid (trans-18:1n-7), a TFA naturally present in ruminants, showed increased efficacy on FFA1 relative to lauric acid (12:0) and the other MUFA (online Supplementary Fig. S1). The low potency of several MUFA precluded accurate calculation of $\mathrm{pEC}_{50}$ and $E_{\max }$.

The $n$-6 PUFA linoleic acid $(18: 2 n$-6) and $\gamma$-linolenic acid (GLA, 18:3n-6) were both comparably potent dual agonists on FFA1 and FFA4, with GLA tending towards higher potency

Table 1. Potency $\left(\mathrm{pEC}_{50}\right)$ and efficacy $\left(E_{\max }\right)$ values for medium- to long-chain saturated NEFA on hFFA1 and hFFA4

\begin{tabular}{|c|c|c|c|c|c|c|c|c|}
\hline \multirow[b]{2}{*}{ Fatty acid } & \multicolumn{4}{|c|}{ FFA1* } & \multicolumn{4}{|c|}{ FFA4† } \\
\hline & $\mathrm{pEC}_{50}$ & SEM & $E_{\max }(\%)$ & SEM & $\mathrm{pEC}_{50}$ & SEM & $E_{\max }(\%)$ & SEM \\
\hline Capric acid (10:0) & 4.60 & 0.15 & 134 & 24 & 5.50 & 0.52 & 59 & 3 \\
\hline Undecylic acid (11:0) & 5.45 & 0.37 & 119 & 29 & 4.52 & 0.03 & 66 & 5 \\
\hline Lauric acid $(12: 0)$ & 4.94 & 0.13 & 116 & 3 & $5 \cdot 12$ & 0.07 & 79 & 2 \\
\hline Tridecylic acid (13:0) & 5.59 & 0.15 & 154 & 44 & $5 \cdot 35$ & 0.09 & 89 & 0.4 \\
\hline Myristic acid $(14: 0)$ & 4.83 & 0.04 & 43 & 26 & 5.44 & 0.08 & 71 & 2 \\
\hline Pentadecanoic acid (15:0) & $<4.5 \ddagger$ & & & & 5.73 & 0.06 & 49 & 3 \\
\hline Palmitic acid $(16: 0)$ & $5 \cdot 19$ & 0.37 & 55 & 9 & $5 \cdot 30$ & 0.23 & 33 & 6 \\
\hline
\end{tabular}

* Determined in a $\mathrm{Ca}^{2+}$ assay, efficacy is given as \% response relative to $100 \mu \mathrm{M}$-lauric acid ( $n 2$ apart from undecylic acid $(n 4)$, myristic acid

$(n 3)$ and pentadecanoic acid $(n 3))$.

† Determined in a $\beta$-arrestin-2 assay, efficacy is given as \% response relative to $100 \mu \mathrm{M}$-TUG-424 ( $n 2$ apart from capric acid $(n 3)$ ).

$\ddagger$ The response did not saturate; therefore, accurate measure of $\mathrm{pEC}_{50}$ and $E_{\max }$ could not be obtained. 
Table 2. Potency $\left(\mathrm{pEC}_{50}\right)$ and efficacy $\left(E_{\max }\right)$ values for MUFA, including trans-MUFA, on hFFA1 and hFFA4

\begin{tabular}{|c|c|c|c|c|c|c|c|c|}
\hline \multirow[b]{2}{*}{ Fatty acid } & \multicolumn{4}{|c|}{ FFA $1^{*}$} & \multicolumn{4}{|c|}{ FFA4† } \\
\hline & $\mathrm{pEC}_{50}$ & SEM & $E_{\max }(\%)$ & SEM & $\mathrm{pEC}_{50}$ & SEM & $E_{\max }(\%)$ & SEM \\
\hline Myristoleic acid (14:1n-5) & $5 \cdot 32$ & 0.12 & 139 & 21 & 5.41 & 0.48 & 110 & 20 \\
\hline Palmitoleic acid $(16: 1 n-7)$ & $5 \cdot 10$ & 0.05 & 116 & 3 & $5 \cdot 31$ & 0.03 & 118 & 14 \\
\hline Oleic acid $(18: 1 n-9)$ & $<4.5 \ddagger$ & & & & 4.91 & 0.02 & 62 & 1 \\
\hline Petroselinic acid $(18: 1 n-12)$ & $<4.5 \ddagger$ & & & & $5 \cdot 03$ & 0.11 & 45 & 6 \\
\hline cis-Vaccenic acid $(18: 1 n-7)$ & $<4.5 \ddagger$ & & & & 5.06 & 0.15 & 57 & 5 \\
\hline Elaidic acid (trans-18:1n-9) & 4.67 & 0.14 & 53 & 18 & \multicolumn{2}{|c|}{ ND§ } & \multicolumn{2}{|c|}{ ND§ } \\
\hline Vaccenic acid (trans-18:1n-7) & $<4.5 \ddagger$ & & & & \multicolumn{2}{|c|}{ ND§ } & \multicolumn{2}{|c|}{ ND§ } \\
\hline Eicosenoic acid $(20: 1 n-9)$ & $<4.5 \ddagger$ & & & & \multicolumn{2}{|c|}{ ND§ } & \multicolumn{2}{|c|}{ ND§ } \\
\hline Erucic acid $(22: 1 n-9)$ & $<5.0 \ddagger$ & & & & \multicolumn{2}{|c|}{ NDß } & \multicolumn{2}{|c|}{ ND§ } \\
\hline Nervonic acid $(24: 1 n-9)$ & \multicolumn{2}{|c|}{ ND§ } & \multicolumn{2}{|c|}{ ND\& } & \multicolumn{2}{|c|}{ ND§ } & \multicolumn{2}{|c|}{ ND§ } \\
\hline
\end{tabular}

ND, not determined.

* Determined on a $\mathrm{Ca}^{2+}$ assay ( $\left.n 2\right)$, efficacy is given as \% response relative to lauric acid.

† Determined on a $\beta$-arrestin-2 assay $(n 3)$, efficacy is given as \% response relative to TUG-424.

¥ The response did not saturate; therefore, accurate measure of $\mathrm{pEC}_{50}$ and $E_{\max }$ could not be obtained.

$\S$ Activity less than $20 \%$ of reference compounds at maximal possible concentration.

(Table 3). Linolelaidic acid (all-trans-18:2n-6), an industrial TFA, was a full agonist of FFA1, but only a partial agonist of FFA4. Dihomo- $\gamma$-linolenic acid $(20: 3 n-6)$, arachidonic acid (20:4n-6) and adrenic acid (22:4n-6) were equally potent agonists on FFA1 and slightly more potent on FFA4, but displayed decreased efficacy on FFA4 with increasing unsaturation and chain length. The longest $n-6$ PUFA tested, adrenic acid was a moderately potent full agonist of both FFA1 and FFA4. The ethylene interrupted $n-6$ PUFA pinolenic acid $(5,9,12-18: 3 n-6)$ was one of the most potent NEFA on both FFA1 and FFA 4 and displayed high efficacy on both receptors.

The $n$-3 PUFA $\alpha$-linolenic acid $(18: 3 n$ - 3$)$ and stearidonic acid $(18: 4 n-3)$ were also potent dual agonists. The more highly unsaturated EPA (20:5n-3) appeared to be more than twice as potent on both receptors compared with $20: 3 n-3$. Of the longer $n$-3 PUFA, $22: 3 n$-3 was the only selective FFA4 agonist among the NEFA, whereas DHA (22:6n-3) was a potent dual agonist.

The conjugated linoleic acids $c 9, t 11-18: 2 n-7$ and $t 10, c 12-18$ : 2n-6 showed moderate dual agonism and slightly higher potency on FFA4 than FFA1, whereas the all-trans isomer $19, t 11-18: 2 n-7$ was equally potent but exhibited low efficacy on both receptors. The $c 9, t 11, t 13-18: 3 n-5$ conjugated NEFA was approximately 10 -fold less potent on FFA1 compared with the conjugated linoleic acids and more potent but less efficacious on FFA4. Ximenynic acid, a conjugated

Table 3. Potency $\left(\mathrm{pEC}_{50}\right)$ and efficacy $\left(E_{\max }\right)$ values for PUFA on hFFA1 and hFFA4

\begin{tabular}{|c|c|c|c|c|c|c|c|c|}
\hline \multirow[b]{2}{*}{ Fatty acid } & \multicolumn{4}{|c|}{ FFA $1^{*}$} & \multicolumn{4}{|c|}{ FFA4† } \\
\hline & $\mathrm{pEC}_{50}$ & SEM & $E_{\max }(\%)$ & SEM & $\mathrm{pEC}_{50}$ & SEM & $E_{\max }(\%)$ & SEM \\
\hline LA $(18: 2 n-6)$ & 4.71 & 0.04 & 143 & 10 & $5 \cdot 34$ & 0.05 & 105 & 7 \\
\hline GLA $(18: 3 n-6)$ & $5 \cdot 15$ & 0.01 & 122 & 14 & 5.65 & 0.03 & 110 & 18 \\
\hline Linolelaidic acid (all-trans-18:2n-6) & 4.48 & 0.11 & 108 & 49 & $5 \cdot 34$ & 0.28 & 40 & 6 \\
\hline Eicosadienoic acid $(20: 2 n-6)$ & $<4.5 \ddagger$ & & & & 4.69 & 0.04 & 80 & 11 \\
\hline DGLA $(20: 3 n-6)$ & 4.51 & 0.28 & 134 & 26 & 4.82 & 0.19 & 120 & 10 \\
\hline AA $(20: 4 n-6)$ & 4.66 & 0.12 & 139 & 6 & 4.92 & 0.20 & 83 & 5 \\
\hline Adrenic acid (22: 4n-6) & 4.61 & 0.14 & 131 & 39 & 4.74 & 0.14 & 60 & 2 \\
\hline Pinolenic acid $(5,9,12-18: 3 n-6)$ & 5.42 & 0.12 & 141 & 33 & $5 \cdot 52$ & 0.09 & 122 & 21 \\
\hline ALA $(18: 3 n-3)$ & $5 \cdot 29$ & 0.02 & 134 & 12 & $5 \cdot 63$ & 0.08 & 101 & 11 \\
\hline SDA $(18: 4 n-3)$ & $5 \cdot 89$ & 0.25 & 83 & 0.2 & 5.90 & 0.10 & 110 & 8 \\
\hline Eicosatrienoic acid $(20: 3 n-3)$ & $<4.5 \ddagger$ & & & & 4.98 & 0.02 & 97 & 21 \\
\hline EPA $(20: 5 n-3)$ & 5.07 & 0.09 & 122 & 2 & $5 \cdot 34$ & 0.02 & 101 & 15 \\
\hline Docosatrienoic acid (22:3n-3) & \multicolumn{2}{|c|}{ ND§ } & \multicolumn{2}{|c|}{ ND§ } & 4.58 & 0.08 & 81 & 37 \\
\hline DHA $(22: 6 n-3)$ & 5.09 & 0.07 & 88 & 19 & $5 \cdot 37$ & 0.03 & 87 & 10 \\
\hline$c 9, t 11-C L A(c 9, t 11-18: 2 n-7)$ & 4.63 & 0.12 & 97 & 35 & 5.04 & 0.11 & 112 & 18 \\
\hline$t 9, t 11-\mathrm{CLA}(t 9, t 11-18: 2 n-7)$ & 4.70 & 0.06 & 38 & 16 & 4.75 & 0.45 & 11 & 1 \\
\hline$t 10, c 12-C L A(t 10, c 12-18: 2 n-6)$ & $4 \cdot 80$ & 0.17 & 84 & 6 & $5 \cdot 24$ & 0.09 & 105 & 9 \\
\hline$\alpha$-Eleostearic acid $(c 9, t 11, t 13-18: 3 n-5)$ & $<4.5 \ddagger$ & & & & 4.69 & 0.10 & 55 & 10 \\
\hline Ximenynic acid & $5 \cdot 33$ & 0.24 & 56 & 7 & 5.00 & 0.06 & 39 & 2 \\
\hline
\end{tabular}

LA, linoleic acid; GLA, $\gamma$-linolenic acid; DGLA, dihomo- $\gamma$-linolenic acid; AA, arachidonic acid; ALA, $\alpha$-linolenic acid; SDA, stearidonic acid; ND, not determined; CLA, conjugated linoleic acid.

${ }^{*}$ Determined on a $\mathrm{Ca}^{2+}$ assay, efficacy is given as \% response relative to lauric acid ( $n 2$, apart from DGLA, adrenic acid, pinolenic acid, eicosatrienoic acid, $\alpha$-eleostearic acid and ximenynic acid for which $n 3$ ).

†Determined in a $\beta$-arrestin-2 assay, efficacy is given as \% response relative to TUG-424 (same replicate numbers as for the Ca ${ }^{2+}$ assay).

$\ddagger$ The response did not saturate, therefore accurate measure of $\mathrm{pEC}_{50}$ and $E_{\max }$ could not be obtained.

$\S$ Activity less than $20 \%$ of reference compounds at maximal possible concentration. 
Table 4. Potency $\left(\mathrm{pEC}_{50}\right)$ and efficacy $\left(E_{\max }\right)$ values for oxidised, branched and other NEFA on hFFA1 and hFFA4

\begin{tabular}{|c|c|c|c|c|c|c|c|c|}
\hline \multirow[b]{2}{*}{ Fatty acid } & \multicolumn{4}{|c|}{ FFA ${ }^{*}$} & \multicolumn{4}{|c|}{ FFA4† } \\
\hline & $\mathrm{pEC}_{50}$ & SEM & $E_{\max }(\%)$ & SEM & $\mathrm{pEC}_{50}$ & SEM & $E_{\max }(\%)$ & SEM \\
\hline 5-Oxo-ETE & \multicolumn{2}{|c|}{ ND $\ddagger$} & \multicolumn{2}{|c|}{ ND $\ddagger$} & 5.48 & 0.22 & 67 & 18 \\
\hline Ricinoleic acid (12S-OH-18:1n-9) & 4.94 & 0.16 & 118 & 13 & 5.88 & 0.11 & 94 & 13 \\
\hline Ricinelaidic acid (12-OH-trans-18:1n-9) & $<4.5 \S$ & & & & $<4.5 \S$ & & & \\
\hline Juniperic acid $(16-\mathrm{OH}-16: 0)$ & 4.68 & 0.01 & 51 & 8 & 5.77 & 0.00 & 68 & 17 \\
\hline 12-Hydroxyoctadecanoic acid (12-OH-18:0) & \multicolumn{2}{|c|}{ ND $\ddagger$} & \multicolumn{2}{|c|}{ ND $\ddagger$} & $5 \cdot 76$ & 0.28 & 88 & 30 \\
\hline 2-Hydroxytetradecanoic acid (2-OH-14:0) & \multirow{2}{*}{\multicolumn{2}{|c|}{$\begin{array}{l}\text { ND } \\
\text { NDł }\end{array}$}} & \multirow{2}{*}{\multicolumn{2}{|c|}{ NDł }} & \multicolumn{2}{|c|}{ ND‡ } & \multicolumn{2}{|c|}{ ND‡ } \\
\hline 2-Hydroxyoleic acid (2-OH-18:1n-9) & & & & & 4.64 & 0.14 & \multicolumn{2}{|c|}{34} \\
\hline 4-Ethyloctanoic acid (4-Et-8:0) & \multicolumn{2}{|c|}{ ND‡ } & \multicolumn{2}{|c|}{ NDł } & & & \multicolumn{2}{|c|}{ ND $\ddagger$} \\
\hline$\alpha$-Lipoic acid & \multicolumn{2}{|c|}{ ND } & \multicolumn{2}{|c|}{ ND $\ddagger$} & & & \multirow{2}{*}{\multicolumn{2}{|c|}{$\begin{array}{l}\text { ND } \ddagger \\
\text { NDt }\end{array}$}} \\
\hline Perfluorotetradecanoic acid & $3 \cdot 81$ & 0.18 & 186 & 23 & & & & \\
\hline
\end{tabular}

5-oxo-ETE, 5-oxo-6E,8Z,11Z,14Z-eicosatetraenoic acid; ND, not determined.

* Determined on a $\mathrm{Ca}^{2+}$ assay, efficacy is given as \% response relative to lauric acid ( $n$ 2, apart from ricinoleic acid ( $n$ 3), rircinelaidic acid ( $\left.n 3\right)$ and 2-hydroxyoleic acid $(n)$ ).

† Determined on a bioluminescence resonance energy transfer assay, efficacy is given as \% response relative to TUG-424 ( $n 3$ ).

$\ddagger$ Activity less than $20 \%$ of reference compounds at maximal possible concentration.

$\S$ The response did not saturate; therefore, accurate measure of $\mathrm{pEC}_{50}$ and $E_{\max }$ could not be obtained.

enyne, was a potent agonist on FFA1 but only a partial agonist on FFA4.

A selection of oxidised, branched and other NEFA was evaluated on FFA1 and FFA4 (Table 4). The keto-NEFA 5-Oxo-ETE, a metabolite of arachidonic acid involved in inflammatory processes by activation of the OXE receptor ${ }^{(45)}$, was found to be inactive on FFA1 and a potent partial agonist on FFA4. Of the saturated hydroxy-NEFA, only juniperic acid (16-OH-16:0) showed activity on FFA1, whereas both 16-OH-16:0 (10-fold more potent) and 12-OH-18:0 were partial agonists on FFA4.

The 12-OH MUFA ricinoleic acid (12S-OH-18:1n-9) stood out among the hydroxy NEFA with high potency and efficacy on both FFA1 and FFA4 with $\mathrm{EC}_{50}$ in the low micromolar range and high efficacy, whereas the corresponding TFA ricinelaidic acid (12-OH-trans-18:1n-9) was found to be more than an order of magnitude less potent. The perflourotetradecanoic acid is a representative synthetic perfluoroalkyl acid, e.g., found in non-stick coatings in food packing and cookware and suspected to be harmful ${ }^{(46)}$. Perflourotetradecanoic acid was a poorly soluble low potency but high efficacy agonist on FFA1.

\section{In vitro characterisation of pinolenic acid}

Pinolenic acid was chosen because of its combined high potency and high efficacy on both receptors, and was thus further evaluated in both the $\mathrm{Ca}^{2+}$ and the $\beta$-arrestin- 2 interaction BRET assay on the human and mouse orthologues of FFA1 and FFA4 (Table 5). Pinolenic acid showed similar potency between human and mouse orthologues of both FFA1 and FFA4, as no statistical differences $(P>0.05)$ were observed between the $\mathrm{pEC}_{50}$ obtained for the two species compared within the same assay format. When comparing between assay formats, it was apparent that pinolenic acid did tend to exhibit lower potency in the $\beta$-arrestin-2 BRET assay than in the $\mathrm{Ca}^{2+}$ assay, with significantly lower $\beta$-arrestin-2 BRET $\mathrm{pEC}_{50}$ values obtained for human FFA1 $(P<0.01)$, mouse FFA1 $(P<0.05)$, mouse FFA $4(P<0.05)$, but not human FFA4 $(P>0 \cdot 05)$. Overall, the results indicated that pinolenic acid shows similar pharmacology between human and mouse orthologues, and therefore should be suitable for in vivo evaluation in mice.

Pinolenic acid has previously been reported to activate the nuclear receptors PPAR $\alpha$ and PPAR $\delta^{(47)}$. We tested the compound at these two receptors and PPAR $\gamma$, and confirmed full activation of PPAR $\alpha$ at $50 \mu \mathrm{m}$ with a small but significant response already at $10 \mu \mathrm{M}$ (online Supplementary Fig. S3). Likewise, pinolenic acid was confirmed to activate PPAR $\delta$ at $50 \mu \mathrm{M}$, but only to approximately $20 \%$ of the level of the selective agonist GW501516. A very small but significant response was also observed at $10 \mu \mathrm{m}$. Pinolenic acid did not significantly activate PPAR $\gamma$ at up to $50 \mu \mathrm{m}$ and did not significantly

Table 5. Potency $\left(\mathrm{pEC}_{50}\right)$ and efficacy $\left(E_{\max }\right)$ values for pinolenic acid on human $(\mathrm{h})$ and mouse $(\mathrm{m})$ orthologues of FFA1 and FFA4

\begin{tabular}{|c|c|c|c|c|c|c|c|c|}
\hline \multirow[b]{2}{*}{ Fatty acid } & \multicolumn{4}{|c|}{$\beta$-Arrestin-2 BRET* } & \multicolumn{4}{|c|}{$\mathrm{Ca}^{2+} \dagger$} \\
\hline & $\mathrm{pEC}_{50}$ & SEM & $E_{\max }$ & SEM & $\mathrm{pEC}_{50}$ & SEM & $E_{\max }$ & SEM \\
\hline hFFA1 & 5.01 & 0.15 & 125 & 5 & \multicolumn{2}{|c|}{$-\ddagger$} & \multicolumn{2}{|c|}{$-\ddagger$} \\
\hline mFFA1 & 4.40 & 0.38 & 124 & 21 & 5.56 & 0.20 & 99 & 7 \\
\hline hFFA4 & \multicolumn{2}{|c|}{$-\ddagger$} & \multicolumn{2}{|c|}{$-\ddagger$} & 5.49 & 0.10 & 86 & 7 \\
\hline mFFA4 & 4.96 & 0.03 & 107 & 2 & 5.44 & 0.08 & 77 & 8 \\
\hline
\end{tabular}

BRET, bioluminescence resonance energy transfer.

${ }^{*}$ Efficacy is given as \% response relative to TUG-424 ( $n 3$ for hFFA1 and mFFA1, $n 4$ for mFFA4). $\dagger$ Efficacy is given as \% response relative to lauric acid ( $n 8$ for hFFA1, $n 4$ for mFFA1 and $n 7 \mathrm{hFFA} 4$ ). $\ddagger$ See values in Table 3 . 
activate any PPAR at concentrations corresponding to the $\mathrm{EC}_{50}$ values at FFA1 and FFA4.

The DMR assay is a label-free technology that captures integrated responses of living cells in real time in a pathway-unbiased yet pathway-sensitive manner. Changes of cytoskeletal rearrangement as a consequence of cell signalling alter the refractive index in the sensing zone above the optical biosensor, which can be monitored by light refraction measurement, and thereby circumvent the need for fluorescent tagging and other labelling that may interfere with the natural cellular processes. Due to the holistic nature of this detection system, it is ideally suited to unravel mechanistic differences of test compounds that mediate their pharmacological effect via targets with pleiotropic signalling ${ }^{(39)}$ but also to expose off-target effects of test compounds under controlled conditions. We therefore characterised pinolenic acid on cells transfected with FFA1, FFA4 or empty vector DNA as control and compared real-time signalling patterns with those induced by the FFA1 agonist TUG- $424^{(48)}$ and the FFA4-selective agonist TUG-891 ${ }^{(38)}$ that we previously developed for both receptors and that have shown beneficial effects on glucose tolerance in rodent models (online Supplementary Fig. S4). We observed robust and concentration-dependent activation by pinolenic acid of both FFA1 and FFA 4 but no evidence for divergent modes of receptor activation compared with the synthetic small molecules (Fig. 1). Importantly, the lack of cell responses in mock-transfected control cells indicates selective agonism via FFA1 and FFA 4 but also the absence of non-specific perturbation of cell function.

\section{Analysis of pine nut oils}

Pine nut oil has the highest proportion of pinolenic acid of any natural oil known. The concentration of pinolenic acid in pine nuts from different regions and pine species is known to vary, with the most common nuts used for food oils being Korean pine nuts and Siberian pine nuts containing $13 \cdot 9-15 \cdot 0 \%$ and $18 \cdot 1-18 \cdot 5 \%$, respectively ${ }^{(49)}$. Therefore, four different Siberian pine nut oils were selected and the fatty acid composition analysed using the GC method to determine the amount of pinolenic acid (Table 6). FA-61 was found to contain the highest amount of pinolenic acid and was selected for in vivo studies in mice. FA-60 and FA-62 contained only slightly lower amounts of pinolenic acid, whereas the amount was less than half in FA-64. Maize oil was chosen as a reference. Analysis confirmed a fatty acid composition as reported in the Danish Food Composition Database ${ }^{(50)}$. The oil did not contain pinolenic acid and only trace amounts of other $18: 3$ fatty acids, and compensatory increased levels of $16: 0,18: 1 n-9$ and $18: 2 n-6$.

\section{Oral glucose tolerance test with pine nut oil and pinolenic acid in mice}

The effects of pine nut oil and corresponding doses of pinolenic acid and pinolenic acid ethyl ester on acute glucose tolerance were investigated in mice using oral administration (Fig. 2). Maize oil contains a distribution of fatty acids that, apart from pinolenic acid, closely resembles pine nut oil, and was therefore used as a control. The FFA1 agonist TUG905, an orally bioavailable potent and selective agonist on both human and murine FFA $1^{(36,51)}$, was used as positive control. Pine nut oil significantly reduced the plasma glucose concentration $30 \mathrm{~min}$ after glucose challenge relative to maize oil $(P<0 \cdot 05)$. Pinolenic acid ethyl ester and TUG-905 significantly lowered the plasma glucose concentration compared with the maize oil-treated group $(t=+30 \mathrm{~min}, \quad P<0 \cdot 001$, $t=+60 \mathrm{~min}, P<0 \cdot 05$ ) (Fig. 2(a)). The free pinolenic acid was compared in a head-to-head study with the pinolenic acid ethyl ester and demonstrated similar glucose-lowering effects (Fig. 2(b)).

\section{Discussion}

The receptors FFA1 and FFA4 have previously been shown to respond to long-chain NEFA and are linked to several physiological processes that could have beneficial effect on metabolic diseases, including enhancement of glucose-dependent insulin secretion for FFA1, anti-inflammatory and insulinsensitising effects for FFA4 and regulation of secretion of incretins and other hormones affecting appetite and plasma glucose $\mathrm{e}^{(19,52)}$. Both receptors are regarded as potential therapeutic targets for the treatment of metabolic diseases and FFA1 is clinically validated through studies with the selective agonist fasiglifam/TAK- $875^{(22)}$. As nutrient-sensing receptors, they are likely mediators of effects of food components counteracting obesity and metabolic diseases ${ }^{(53,54)}$.
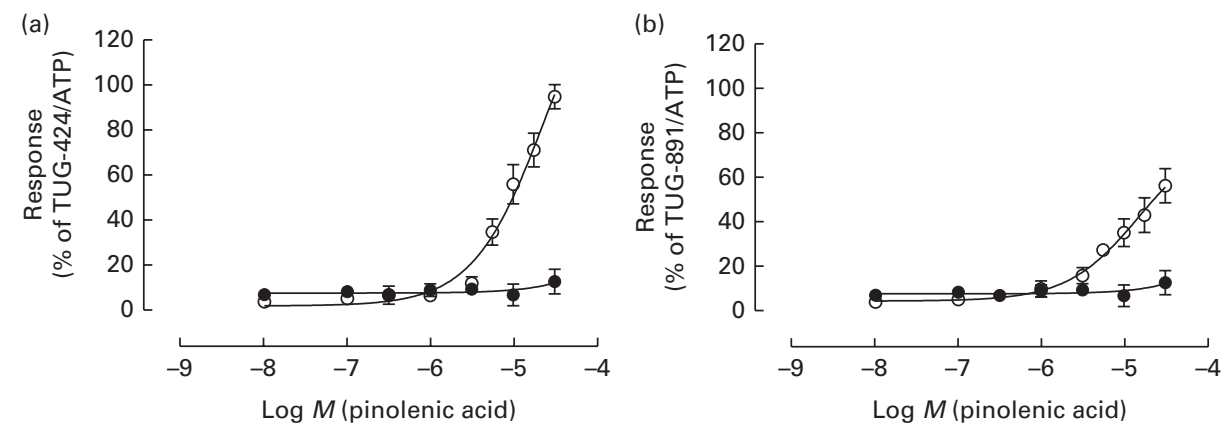

Fig. 1. Concentration-response curves of pinolenic acid from the dynamic mass redistribution assay in FFA1-transfected (a), FFA4-transfected (b) and mocktransfected HEK 293 cells. Values are means, with their standard errors of three independent experiments represented by vertical bars. (a) -O-, hFFA1-HEK; --, HEK 293. (b) -O-, hFFA4-HEK; -—-, HEK 293. 
Table 6. Fatty acid (FA) composition of pine nut oils and maize oil determined by GC analysis* (Mean values and standard deviations)

\begin{tabular}{|c|c|c|c|c|c|c|c|c|c|c|}
\hline & \multicolumn{2}{|c|}{ FA-60 } & \multicolumn{2}{|c|}{ FA-61 } & \multicolumn{2}{|c|}{ FA-62 } & \multicolumn{2}{|c|}{ FA-64 } & \multicolumn{2}{|c|}{ Maize oil } \\
\hline & Mean & SD & Mean & SD & Mean & SD & Mean & SD & Mean & SD \\
\hline Palmitic acid $(16: 0)$ & 4.7 & 0.1 & $4 \cdot 1$ & 0.0 & $4 \cdot 1$ & 0.0 & $4 \cdot 8$ & 0.0 & $10 \cdot 3$ & 0.0 \\
\hline Stearic acid $(18: 0)$ & $1 \cdot 8$ & 0.4 & $2 \cdot 3$ & $0 \cdot 2$ & $2 \cdot 7$ & 0.0 & 1.9 & 0.0 & 1.9 & 0.0 \\
\hline Oleic acid $(18: 1 n-9)$ & $24 \cdot 3$ & 1.4 & $21 \cdot 8$ & 0.6 & $23 \cdot 0$ & 0.3 & $16 \cdot 7$ & $0 \cdot 1$ & $29 \cdot 2$ & 0.1 \\
\hline Linoleic acid $(18: 2 n-6)$ & $46 \cdot 8$ & 0.8 & $47 \cdot 7$ & 0.6 & $46 \cdot 7$ & 0.2 & $65 \cdot 6$ & $0 \cdot 1$ & $57 \cdot 1$ & 0.0 \\
\hline Pinolenic acid $(5,9,12-18: 3 n-6)$ & $19 \cdot 1$ & $1 \cdot 1$ & $20 \cdot 9$ & 0.5 & $20 \cdot 2$ & 0.1 & $8 \cdot 1$ & 0.0 & 0.0 & 0.0 \\
\hline$\alpha$-Linolenic acid $(18: 3 n-3)$ & 0.5 & 0.0 & 0.5 & 0.0 & 0.5 & 0.0 & 1.5 & 0.0 & $1 \cdot 3$ & 0.0 \\
\hline Eicosenoic acid $(20: 1 n-9)$ & $1 \cdot 0$ & 0.1 & $1 \cdot 1$ & 0.1 & $1 \cdot 1$ & 0.0 & 0.6 & 0.0 & 0.2 & 0.0 \\
\hline Eicosadienoic acid $(20: 2 n-6)$ & 0.5 & 0.0 & 0.6 & 0.0 & 0.6 & 0.0 & 0.3 & 0.0 & 0.0 & 0.0 \\
\hline Eicosatrienoic acid $(20: 3 n-3)$ & $1 \cdot 1$ & 0.1 & $1 \cdot 0$ & 0.0 & 1.0 & 0.1 & 0.6 & 0.0 & 0.0 & 0.0 \\
\hline
\end{tabular}

*Means and SD are calculated from three independent replicates.

Apart from the screening reported with the deorphanisation of the receptors ${ }^{(9-12)}$, the activity of dietary NEFA on these receptors has not been investigated. Here, we elucidate the agonist properties of a broad selection of long-chain NEFA and further elaborate the structure-activity relationships of NEFA on FFA1 and FFA4. Since it is probable that the two receptors can act co-operatively or synergistically against T2D, we have focused on the effect of the NEFA that CO-activate FFA1 and FFA4.

$\mathrm{A} \mathrm{Ca}^{2+}$ assay was employed for screening of FFA1, since increased intracellular $\mathrm{Ca}^{2+}$ is the pathway leading to insulin release $^{(55)}$. $\beta$-Arrestin recruitment is relevant to the function of FFA 4 as this pathway has been implicated in the anti-inflammatory and insulin-sensitising effects of the receptor ${ }^{(29)}$; thus, FFA4 screening was performed using a $\beta$-arrestin- 2 interaction BRET assay. Many of the NEFA investigated here have also been previously characterised on FFA1 and FFA4 by others $^{(9-12)}$. Our data generally correspond well with these results. The saturated NEFA were found to be 7 - to 10-fold more potent on FFA4 than the reported $\mathrm{Ca}^{2+}$ data by Hirasawa et al. ${ }^{(12)}$. However, they employed a $\mathrm{Ca}^{2+}$. mobilisation assay, whereas we have used a $\beta$-arrestin-2 recruitment assay, and the discrepancy could possibly be explained by a signalling bias towards $\beta$-arrestin- 2 for these NEFA. None of the previous reports include efficacy data, which is a factor that can result in significant functional differences. For example, FFA1 agonists with high efficacy in $\mathrm{Ca}^{2+}$ response in cells expressing the receptor at physiological levels have been associated with the release of glucagon-like peptide-1, whereas partial FFA1 agonists appear to lack this property $^{(23)}$. Discrepancies between the reported data for some of the NEFA can probably be explained by their relatively modest potency combined with poor solubility and risk of micelle formation. Furthermore, the amount of bovine serum albumin used in the different assays can dramatically affect the free concentration of NEFA.

The MUFA myristoleic acid was identified as a potent agonist on FFA1 with activity in the low micromolar range and high efficacy. In addition, four MUFA that have previously been reported to activate FFA1 and FFA4 were confirmed, including oleic acid (18:1n-9), especially abundant in Mediterranean diet, and palmitoleic acid (16:1n-7), a 'lipokine' mediating metabolic homeostasis between organs ${ }^{(56)}$. The potencies obtained on FFA4 for the $n-6$ NEFA GLA, dihomo$\gamma$-linolenic acid and adrenic acid corresponded to the values reported by Hirasawa et $a l^{(12)}$, with GLA appearing to be more potent than the two others. The compounds varied considerably in efficacy, although for many compounds, the curves did not level sufficiently to determine the accurate potency and efficacy. For FFA1, lower potencies (approximately 2 -fold) were found for the longer $n-6$ NEFA with the decreased potency being more pronounced for $20: 2 n-6$ and dihomo- $\gamma$-linolenic acid ( $>4$-fold) compared with previously
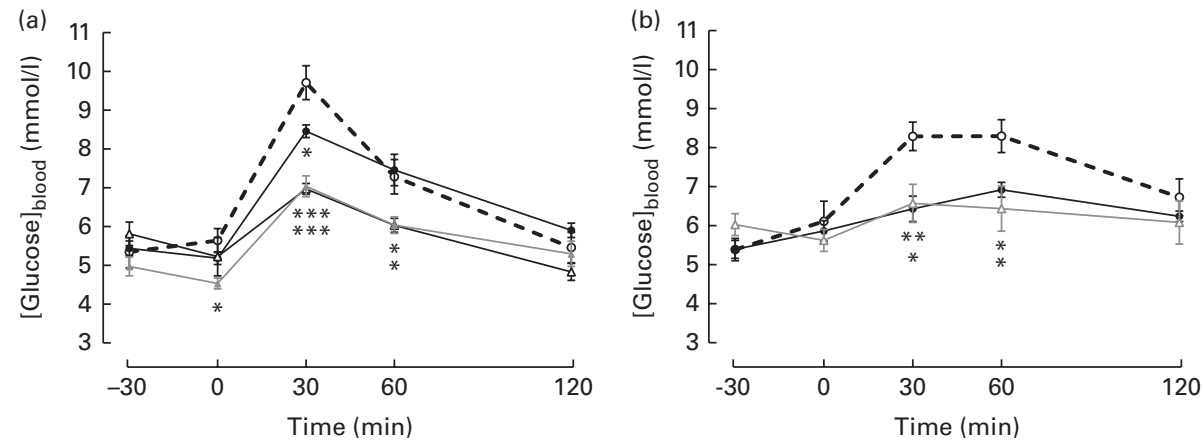

Fig. 2. Oral glucose tolerance test in mice, compounds dosed orally $30 \mathrm{~min}$ before glucose challenge. Values are means, with their standard errors represented by vertical bars ( $n$ 8). Mean value was significantly different: ${ }^{\star} P<0.05$, ${ }^{\star \star} P<0.01$, ${ }^{\star \star \star} P<0.001$. In (b), one high value $(>12 \mathrm{~mm})$ excluded at $t=+30$ in free acid

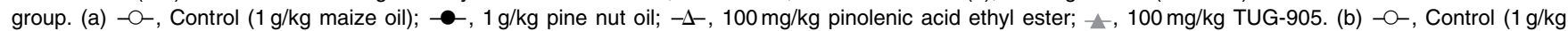
maize oil); -๑, $100 \mathrm{mg} / \mathrm{kg}$ pinolenic acid (free acid); $-\triangle_{-}, 100 \mathrm{mg} / \mathrm{kg}$ pinolenic acid (ethyl ester). 
reported data ${ }^{(11)}$. The positional isomer of GLA, pinolenic acid, was among the most potent and efficacious NEFA on both receptors. All $n-3$ NEFA tested on FFA1 have been reported to be agonists in the low micromolar range ${ }^{(9-11)}$. This was confirmed with the exception of $22: 3 n-3$, which showed low activity in our assay, but has previously been reported with $\mathrm{EC}_{50}=7 \mu \mathrm{M}^{(11)}$. The difference might be explained by assay variance or by $22: 3 n-3$ being a low efficacy agonist relative to lauric acid (12:0). $22: 3 n-3$ was also the only NEFA deviating substantially from the previously published data on FFA4, being a partial agonist in our assay but previously reported to be inactive ${ }^{(12)}$. This could possibly be explained by a bias of $22: 3 n-3$ towards the $\beta$-arrestin- 2 pathway. Stearidonic acid, a precursor of EPA, was also identified as a particularly potent agonist on both FFA1 and FFA4.

In contrast to most of the other unsaturated fatty acid, TFA are generally associated with detrimental health effects, also in relation to metabolic diseases ${ }^{(57)}$. The TFA elaidic acid, vaccenic acid and linolelaidic acid all displayed relatively low potency on FFA1 and low efficacy or no activity on FFA4. The conjugated NEFA, in general, exhibited intermediate potencies on both receptors, apart from the all trans-isomer that was found to have low efficacy. Conjugated linoleic acids are associated with several beneficial health effects, but may have a detrimental effect on metabolic diseases ${ }^{(58)}$. The conjugated linoleic acids have previously been reported as FFA1 agonists with potencies similar or somewhat lower to what we have shown ${ }^{(59)}$.

Oxidation products of fatty acids often act as potent and specific signalling molecules, including members of the prostanoid, leukotriene, lipoxin and resolvin classes. Ricinoleic acid (12S-OH-18: $1 n-9)$ appeared to be a more potent and efficacious agonist on FFA4 compared with the corresponding non-hydroxylated oleic acid. The same trend was also observed for the saturated NEFA juniperic acid (16-OH-16:0) compared with palmitic acid (16:0) and for 12-OH-18:0 compared with 18:0, however, to a smaller degree. Thus, hydroxylation of NEFA does in several cases seem to increase both potency and efficacy on FFA4. This is in agreement with a recent publication linking a hydroxy-MUFA to intestinal homeostasis through FFA1 ${ }^{(60)}$.

The most potent dual agonists for FFA1 and FFA 4 included the ethylene interrupted $n-6$ PUFA pinolenic acid $(5,9,12-$ $18: 3 n-6)$ and the $n$-3 PUFA stearidonic acid (18:4n-3), both with single digit $\mu \mathrm{M} \mathrm{EC}_{50}$-values on both receptors. Pinolenic acid was chosen for further investigation partly due to a tendency towards higher efficacy for this compound. Stearidonic acid $(18: 4 n-3)$ is an intermediate in the conversion of $\alpha$-linolenic acid (18:3n-3) to EPA and the longer chain $n$-3 PUFA, and its low general abundance can be explained by its efficiency as an enzyme substrate ${ }^{(61)}$. In contrast, pinolenic acid is not converted to arachidonic acid, and is therefore not a likely precursor of eicosanoids, nor has it been found to give rise to chain shortened metabolites ${ }^{(62-64)}$. The C2-elongated pinolenic acid 7,11,14-20:3n-6 is, however, reported to be formed in macrophages ${ }^{(65)}$ and to decrease the formation of $\mathrm{PGE}_{2}$ production by competition with arachidonic acid for the cyclo-oxygensae-2 enzyme ${ }^{(66)}$.
It is notable that pine nut oil, containing up to $20 \%$ pinolenic acid, has been associated with effects that potentially can be explained by activity on FFA1 and FFA4. Supplementation of pine nut oil to mice on a high fat diet has been shown to reduce weight gain and intramuscular lipid accumulation compared with soyabean oil ${ }^{(47)}$. This was explained at least partly by dual agonism on PPAR $\alpha$ and PPAR $\delta$, nuclear receptors activated by NEFA that are involved in metabolism ${ }^{(67)}$. In vivo experiments in rats using Korean pine nut oil also revealed beneficial effects on degenerative disorders such as hypercholesterolaemia, thrombosis and hypertension ${ }^{(62)}$. Additionally, treatment of human hepatocytes with pinolenic acid-enriched NEFA extracts of hydrolysed Korean pine nut oil showed an LDL-lowering effect mediated by an increased cholesterol uptake $^{(68)}$. The effect of Korean pine nut oil has also been investigated on overweight post-menopausal women and showed appetite suppressant effects and a significant increase in the levels of the satiety hormones cholecystokinin- 8 and glucagon-like peptide-1 compared with olive oil-treated women $^{(69)}$. We confirmed activity of pinolenic acid on PPAR $\alpha$ and PPAR $\delta$ at higher concentrations, but did not observe any activity at $3 \mu \mathrm{M}$ concentration, corresponding to $\mathrm{EC}_{50}$ at FFA1 and FFA4. Furthermore, robust and similar activities were observed with pinolenic acid in the label-free DMR assay in FFA1- and FFA4-transfected cells, whereas the compound was inactive in non-transfected cells, indicating that pinolenic acid-induced cell activation is FFA1 and FFA4 dependent. Together with the expected higher exposure of cell surface receptors compared with nuclear receptors to pinolenic acid, this suggests FFA1 and FFA4 as primary targets for pinolenic acid. Moreover, the complex pharmacology of especially FFA1 has raised the question of whether NEFA and synthetic compounds engage the same signalling mechanisms ${ }^{(70)}$, and the similarity between DMR traces of pinolenic acid and synthetic receptor ligands suggests that they do in this case.

Effects such as glucose-dependent insulin secretion, protection of pancreatic islets, anti-inflammatory and insulinsensitising effects and secretion of appetite- and glucoseregulating hormones have been linked to either FFA1 or FFA4. The combination of these effects could be expected to robustly counteract metabolic diseases. From this rationale, co-activation of FFA1 and FFA4 appears to be an attractive strategy for treatment of metabolic diseases. Even dual FFA1/FFA4 agonists with relatively moderate potency, such as pinolenic acid, could have potential to give robust effects due to synergistic activities between the receptors. Indeed, pinolenic acid is already associated with some of the effects that would be expected from dual FFA1/FFA4 agonism. Although further studies are required to confirm the effects of pinolenic acid and elucidate to which degree FFA1 and FFA 4 are responsible for these, the compound appears to be an interesting candidate for an active ingredient in diets to prevent or counteract metabolic diseases.

\section{Supplementary material}

To view supplementary material for this article, please visit http://dx.doi.org/10.1017/S000711451500118X 


\section{Acknowledgements}

We thank Professor Karsten Kristiansen for useful discussions and Professor Nils J. Færgeman for access to GC equipment. We are grateful to Corning ${ }^{\circledR}$ and Perkin Elmer for providing us with support on the Epic ${ }^{\circledR}$ biosensor and the Enspire multimode microplate reader.

The present study was supported by the Danish Council for Strategic Research (grant 11-116196).

None of the authors has any conflict of interest to declare.

The authors' contributions are as follows: T. U. conceived the study; E. C. and T. U. selected compounds for the study; E. C. acquired or synthesised test compounds, performed solubility tests and dissolved NEFA; K. R. W. and L. J. performed $\mathrm{Ca}$ and $\beta$-arrestin-2 assays; M. G. and K. S. performed DMR assays; R. K. P. designed and performed PPAR assays; C. J. S. and E. T. W. performed animal studies; E. C., T. U., R. K. P., E. S., K. R. W., B. D. H., G. M., M. G., E. K., C. J. S. and M. A. C. analysed the data; E. C. and T. U. wrote the manuscript; G. M., M. A. C., E. K., C. S. E., K. R. W., B. D. H., C. J. S., M. G., E. S. and R. K. P. critically read and provided feedback; G. M., M. A. C., E. K., T. U., C. S. E. and B. D. H. designed and supervised the studies. All authors approved the final manuscript.

\section{References}

1. International Diabetes Federation (2013) IDF Diabetes Atlas, 2014 Update, 6th ed. Brussels: International Diabetes Federation. http://www.idf.org/diabetesatlas

2. Perez-Martinez P, Garcia-Rios A, Delgado-Lista J, et al. (2011) Mediterranean diet rich in olive oil and obesity, metabolic syndrome and diabetes mellitus. Curr Pharm Des 17, 769-777.

3. Heikkila HM, Krachler B, Rauramaa R, et al. (2014) Diet, insulin secretion and insulin sensitivity - the DoseResponses to Exercise Training (DR's EXTRA) Study (ISRCTN45977199). Br J Nutr 112, 1530-1541.

4. Hirahatake KM, Slavin JL, Maki KC, et al. (2014) Associations between dairy foods, diabetes, and metabolic health: potential mechanisms and future directions. Metabolism $\mathbf{6 3}$, 618-627.

5. Jiang X, Zhang D \& Jiang W (2014) Coffee and caffeine intake and incidence of type 2 diabetes mellitus: a meta-analysis of prospective studies. Eur J Nutr 53, 25-38.

6. Wu JH, Micha R, Imamura F, et al. (2012) Omega-3 fatty acids and incident type 2 diabetes: a systematic review and metaanalysis. Br J Nutr 107, Suppl. 2, S214-S227.

7. Yanai H, Hamasaki H, Katsuyama H, et al. (2015) Effects of intake of fish or fish oils on the development of diabetes. I Clin Med Res 7, 8-12.

8. Ran-Ressler RR, Bae S, Lawrence P, et al. (2014) Branchedchain fatty acid content of foods and estimated intake in the USA. Br J Nutr 112, 565-572.

9. Kotarsky K, Nilsson NE, Flodgren E, et al. (2003) A human cell surface receptor activated by free fatty acids and thiazolidinedione drugs. Biochem Biophys Res Commun 301 406-410.

10. Itoh Y, Kawamata Y, Harada M, et al. (2003) Free fatty acids regulate insulin secretion from pancreatic $\beta$ cells through GPR40. Nature 422, 173-176.

11. Briscoe CP, Tadayyon M, Andrews JL, et al. (2003) The orphan $G$ protein-coupled receptor GPR 40 is activated by medium and long chain fatty acids. I Biol Chem $\mathbf{2 7 8}$, $11303-11311$

12. Hirasawa A, Tsumaya K, Awaji T, et al. (2005) Free fatty acids regulate gut incretin glucagon-like peptide-1 secretion through GPR120. Nat Med 11, 90-94.

13. Le Poul E, Loison C, Struyf S, et al. (2003) Functional characterization of human receptors for short chain fatty acids and their role in polymorphonuclear cell activation. J Biol Chem 278, 25481-25489.

14. Brown AJ, Goldsworthy SM, Barnes AA, et al. (2003) The Orphan G protein-coupled receptors GPR41 and GPR43 are activated by propionate and other short chain carboxylic acids. J Biol Chem 278, 11312-11319.

15. Nilsson NE, Kotarsky K, Owman C, et al. (2003) Identification of a free fatty acid receptor, FFA2R, expressed on leukocytes and activated by short-chain fatty acids. Biochem Biophys Res Commun 303, 1047-1052.

16. Natarajan N \& Pluznick JL (2014) From microbe to man: the role of microbial short chain fatty acid metabolites in host cell biology. Am J Physiol Cell Physiol 307, C979-C985.

17. Cani PD, Everard A \& Duparc T (2013) Gut microbiota, enteroendocrine functions and metabolism. Curr Opin Pharmacol 13, 935-940.

18. Ulven T (2012) Short-chain free fatty acid receptors FFA2/ GPR43 and FFA3/GPR41 as new potential therapeutic targets. Front Endocrinol 3, 111.

19. Offermanns S (2014) Free fatty acid (FFA) and hydroxy carboxylic acid (HCA) receptors. Annu Rev Pharmacol Toxicol 54, 407-434.

20. Briscoe CP, Peat AJ, McKeown SC, et al. (2006) Pharmacological regulation of insulin secretion in MIN6 cells through the fatty acid receptor GPR40: identification of agonist and antagonist small molecules. Br J Pharmacol 148, 619-628.

21. Del Guerra S, Bugliani M, D'Aleo V, et al. (2010) G-proteincoupled receptor 40 (GPR40) expression and its regulation in human pancreatic islets: the role of type 2 diabetes and fatty acids. Nutr Metab Cardiovasc Dis 20, 22-25.

22. Burant CF, Viswanathan P, Marcinak J, et al. (2012) TAK-875 versus placebo or glimepiride in type 2 diabetes mellitus: a phase 2, randomised, double-blind, placebo-controlled trial. Lancet 379, 1403-1411.

23. Luo J, Swaminath G, Brown SP, et al. (2012) A potent class of GPR40 full agonists engages the enteroinsular axis to promote glucose control in rodents. PLOS ONE 7, e 46300.

24. Liou AP, Lu X, Sei Y, et al. (2011) The G-protein-coupled receptor GPR40 directly mediates long-chain fatty acidinduced secretion of cholecystokinin. Gastroenterology 140, 903-912.

25. Edfalk S, Steneberg P \& Edlund H (2008) Gpr40 is expressed in enteroendocrine cells and mediates free fatty acid stimulation of incretin secretion. Diabetes 57, 2280-2287.

26. Engelstoft MS, Park WM, Sakata I, et al. (2013) Seven transmembrane $G$ protein-coupled receptor repertoire of gastric ghrelin cells. Mol Metab 2, 376-392.

27. Gong Z, Yoshimura M, Aizawa S, et al. (2014) G proteincoupled receptor 120 signaling regulates ghrelin secretion in vivo and in vitro. Am J Physiol Endocrinol Metab 306, E28-E35.

28. Paulsen SJ, Larsen LK, Hansen G, et al. (2014) Expression of the fatty acid receptor GPR120 in the gut of dietinduced-obese rats and its role in GLP-1 secretion. PLOS ONE 9, e88227.

29. Oh DY, Talukdar S, Bae EJ, et al. (2010) GPR120 is an omega-3 fatty acid receptor mediating potent anti-inflammatory and insulin-sensitizing effects. Cell 142, 687-698. 
30. Stone VM, Dhayal S, Brocklehurst KJ, et al. (2014) GPR120 (FFAR4) is preferentially expressed in pancreatic delta cells and regulates somatostatin secretion from murine islets of Langerhans. Diabetologia 57, 1182-1191.

31. Li X, Yu Y \& Funk CD (2013) Cyclooxygenase-2 induction in macrophages is modulated by docosahexaenoic acid via interactions with free fatty acid receptor 4 (FFA4). FASEB J 27, 4987-4997.

32. Cintra DE, Ropelle ER, Moraes JC, et al. (2012) Unsaturated fatty acids revert diet-induced hypothalamic inflammation in obesity. PLOS ONE 7, e30571.

33. Wellhauser L \& Belsham DD (2014) Activation of the omega-3 fatty acid receptor GPR120 mediates anti-inflammatory actions in immortalized hypothalamic neurons. J Neuroinflammation 11, 60.

34. Ichimura A, Hirasawa A, Poulain-Godefroy O, et al. (2012) Dysfunction of lipid sensor GPR120 leads to obesity in both mouse and human. Nature 483, 350-354.

35. Tyagi R, Shimpukade B, Blattermann S, et al. (2012) A concise synthesis of the potent inflammatory mediator 5-oxo-ETE. MedChemComm 3, 195-198.

36. Hudson BD, Shimpukade B, Mackenzie AE, et al. (2013) The pharmacology of TUG-891, a potent and selective agonist of the free fatty acid receptor 4 (FFA4/GPR120), demonstrates both potential opportunity and possible challenges to therapeutic agonism. Mol Pharmacol 84, 710-725.

37. Hudson BD, Christiansen E, Tikhonova IG, et al. (2012) Chemically engineering ligand selectivity at the free fatty acid receptor 2 based on pharmacological variation between species orthologs. FASEB J 26, 4951-4965.

38. Shimpukade B, Hudson BD, Hovgaard CK, et al. (2012) Discovery of a potent and selective GPR120 agonist. $J$ Med Chem 55, 4511-4515.

39. Schroder R, Janssen N, Schmidt J, et al. (2010) Deconvolution of complex $G$ protein-coupled receptor signaling in live cells using dynamic mass redistribution measurements. Nat Biotechnol 28, 943-949.

40. Schroder R, Schmidt J, Blattermann S, et al. (2011) Applying label-free dynamic mass redistribution technology to frame signaling of $G$ protein-coupled receptors noninvasively in living cells. Nat Protoc 6, 1748-1760.

41. Christie WW (1993) Advances in Lipid Methodology - Two. Dundee: P.J. Barnes \& Associates (The Oily Press).

42. Serth J, Lautwein A, Frech M, et al. (1991) The inhibition of the GTPase activating protein-Ha-ras interaction by acidic lipids is due to physical association of the C-terminal domain of the GTPase activating protein with micellar structures. EMBO J 10, 1325-1330.

43. Kumar A, Bullard RL, Patel P, et al. (2011) Non-esterified fatty acids generate distinct low-molecular weight amyloid- $\beta$ (A $\beta 42)$ oligomers along pathway different from fibril formation. PLOS ONE 6, e18759.

44. Mukerjee P \& Mysels KJ (1971) Critical Micelle Concentrations of Aqueous Surfactant Systems (NSRDS-NBS 36). Washington, DC: US Government Printing Office.

45. Powell WS \& Rokach J (2013) The eosinophil chemoattractant 5-oxo-ETE and the OXE receptor. Prog Lipid Res 52, 651-665.

46. Vestergren R, Berger U, Glynn A, et al. (2012) Dietary exposure to perfluoroalkyl acids for the Swedish population in 1999, 2005 and 2010. Environ Int 49, 120-127.

47. Le NH, Shin S, Tu TH, et al. (2012) Diet enriched with Korean pine nut oil improves mitochondrial oxidative metabolism in skeletal muscle and brown adipose tissue in diet-induced obesity. J Agric Food Chem 60, 11935-11941.
48. Christiansen E, Urban C, Merten N, et al. (2008) Discovery of potent and selective agonists for the free fatty acid receptor 1 (FFA(1)/GPR40), a potential target for the treatment of type II diabetes. J Med Chem 51, 7061-7064.

49. Wolff RL, Pedrono F, Pasquier E, et al. (2000) General characteristics of Pinus spp. seed fatty acid compositions, and importance of $\Delta 5$-olefinic acids in the taxonomy and phylogeny of the genus. Lipids 35, 1-22.

50. Danish Food Composition Database. http://www.foodcomp. $\mathrm{dk} / \mathrm{v} 7 / \mathrm{fcdb}$ details.asp?FoodId $=0153$

51. Christiansen E, Due-Hansen ME, Urban C, et al. (2012) Free fatty acid receptor 1 (FFA1/GPR40) agonists: mesylpropoxy appendage lowers lipophilicity and improves ADME properties. J Med Chem 55, 6624-6628.

52. Watterson KR, Hudson BD, Ulven T, et al. (2014) Treatment of type 2 diabetes by free fatty acid receptor agonists. Front Endocrinol (Lausanne) 5, 137.

53. Milligan G, Ulven T, Murdoch H, et al. (2014) G-proteincoupled receptors for free fatty acids: nutritional and therapeutic targets. Br J Nutr 111, Suppl. 1, S3-S7.

54. Dranse HJ, Kelly ME \& Hudson BD (2013) Drugs or diet? developing novel therapeutic strategies targeting the free fatty acid family of GPCRs. Br J Pharmacol 170, 696-711.

55. Fujiwara K, Maekawa F \& Yada T (2005) Oleic acid interacts with GPR40 to induce $\mathrm{Ca}^{2+}$ signaling in rat islet $\beta$-cells: mediation by PLC and L-type $\mathrm{Ca}^{2+}$ channel and link to insulin release. Am J Physiol Endocrinol Metab 289, E670-E677.

56. Cao H, Gerhold K, Mayers JR, et al. (2008) Identification of a lipokine, a lipid hormone linking adipose tissue to systemic metabolism. Cell 134, 933-944.

57. Micha R \& Mozaffarian D (2009) Trans fatty acids: effects on metabolic syndrome, heart disease and diabetes. Nat Rev Endocrinol 5, 335-344.

58. Kennedy A, Martinez K, Schmidt S, et al. (2010) Antiobesity mechanisms of action of conjugated linoleic acid. I Nutr Biochem 21, 171-179.

59. Schmidt J, Liebscher K, Merten N, et al. (2011) Conjugated linoleic acids mediate insulin release through islet $G$ protein-coupled receptor FFA1/GPR40. J Biol Chem 286, 11890-11894.

60. Miyamoto J, Mizukure T, Park SB, et al. (2014) A gut microbial metabolite of linoleic acid, 10-hydroxy-cis-12octadecenoic acid, ameliorates intestinal epithelial barrier impairment partially via GPR40/MEK-ERK pathway. $J$ Biol Chem 290, 2902-2918.

61. Walker CG, Jebb SA \& Calder PC (2013) Stearidonic acid as a supplemental source of omega-3 polyunsaturated fatty acids to enhance status for improved human health. Nutrition 29, 363-369.

62. Sugano M, Ikeda I, Wakamatsu K, et al. (1994) Influence of Korean pine (Pinus koraiensis)-seed oil containing cis-5, cis-9, cis-12-octadecatrienoic acid on polyunsaturated fatty acid metabolism, eicosanoid production and blood pressure of rats. Br J Nutr 72, 775-783.

63. Tanaka T, Takimoto T, Morishige J, et al. (1999) Nonmethylene-interrupted polyunsaturated fatty acids: effective substitute for arachidonate of phosphatidylinositol. Biochem Biophys Res Commun 264, 683-688.

64. Tanaka T, Uozumi S, Morito K, et al. (2014) Metabolic conversion of C20 polymethylene-interrupted polyunsaturated fatty acids to essential fatty acids. Lipids 49, 423-429.

65. Chuang LT, Tsai PJ, Lee CL, et al. (2009) Uptake and incorporation of pinolenic acid reduces $n-6$ polyunsaturated fatty acid and downstream prostaglandin formation in murine macrophage. Lipids $\mathbf{4 4}, 217-224$. 
66. Huang WC, Tsai PJ, Huang YL, et al. (2014) $\mathrm{PGE}_{2}$ production is suppressed by chemically-synthesized $\Delta 7$-eicosatrienoic acid in macrophages through the competitive inhibition of COX-2. Food Chem Toxicol 66, 122-133.

67. Nakamura MT, Yudell BE \& Loor JJ (2014) Regulation of energy metabolism by long-chain fatty acids. Prog Lipid Res 53, 124-144.

68. Lee JW, Lee KW, Lee SW, et al. (2004) Selective increase in pinolenic acid (all-cis-5,9,12-18:3) in Korean pine nut oil by crystallization and its effect on LDL-receptor activity. Lipids 39, 383-387.

69. Pasman WJ, Heimerikx J, Rubingh CM, et al. (2008) The effect of Korean pine nut oil on in vitro CCK release, on appetite sensations and on gut hormones in post-menopausal overweight women. Lipids Health Dis 7, 10.

70. Mancini AD \& Poitout V (2013) The fatty acid receptor FFA1/ GPR40 a decade later: how much do we know? Trends Endocrinol Metab 24, 398-407. 